\title{
EXPERIMENTAL MODEL OF CANDIDA ALBICANS (SEROTYPES A AND B) ADHERENCE IN VITRO
}

\author{
Maria de Fátima Costa Pires ${ }^{1 *}$; Benedito Corrêa ${ }^{2}$; Walderez Gambale²; Claudete Rodrigues Paula ${ }^{2}$ \\ ${ }^{1}$ Secão de Microscopia Eletrônica, Instituto Adolfo Lutz, São Paulo, SP, Brasil. ${ }^{2}$ Departamento de Microbiologia, \\ Instituto de Ciências Biomédicas, Universidade de São Paulo, São Paulo, SP, Brasil
}

Submitted: April 28, 2000; Returned to authors for corrections: March 20, 2001; Approved: July 23, 2001

\begin{abstract}
The adherence of Candida albicans is considered an important virulence factor since it determines the colonization of the yeast in various regions of the host, being the initial cause of the infection. In this work we studied the adherence of C. albicans (serotypes A and B) to HeLa and Vero cells after culture for $18 \mathrm{~h}$ and 30 $\mathrm{h}$ in chemically defined medium (YNB) plus carbohydrate sources such as glucose, sucrose, maltose, galactose and mannose $(500 \mathrm{mM})$. Each assay was performed in triplicate. The best results were obtained with the medium containing glucose. The adherence was greatest in $18 \mathrm{~h}$ cultures at $37^{\circ} \mathrm{C}$ and at $1 \mathrm{~h}$ contact time. The interaction of yeast cells with the host cells was studied by scanning microscopy.
\end{abstract}

Key words: Candida albicans, adherence, serotypes

\section{INTRODUCTION}

Adherence is the first stage in Candida albicans colonization, with subsequent dissemination of the yeast when a disequilibrium in host defense occurs. Adherence involves surface macromolecules that interact with macromolecules on the surface of, or adsorbed to, the substrate (32). There is evidence that $C$. albicans may produce more than one adhering structure or that more than one of these structures, such as proteins, chitin and lipids, may be involved in this process. Most reports in the literature indicate a mannoprotein as the adhesin $(9,18,30,33)$. The receptors of various tissues to which C. albicans binds have not been well characterized, although several investigators have suggested that they may be fibronectins, certain phospholipids, L-fucose, mannose, Nacetyl-D-glucosamine, mucins, laminins, and collagen $(9,12,20,40)$. Because of the importance and the significance of adherence, several in vivo and in vitro models have been developed to quantitate and characterize $C$. albicans adherence to cellular and inanimate surfaces $(4,6,7,9,10,11,13,16$, $17,18,19,20,22,23,24,26,34,35)$. These studies have shown that various factors interfere with yeast adherence to epithelial cells in vitro, especially factors related to the yeast itself, to epithelial cells and to still unclear environmental factors. Diverse results have been reported in recent studies, probably due to the use of different adherence techniques, growth phases, culture media, incubation and contact times, yeast and sugar concentrations, and cell types. Among these variants we should also mention the different strains of $C$. albicans with their intrinsic serotype characteristics, which also affect the results. This study is needed to clarify the mechanism of $C$. albicans adherence and for a better standardization of the techniques employed. The use of scanning and transmission electron microscopy techniques may help to elucidate some of the obscure points in these assays. On this basis, the objective of the present study was to establish an experimental model of adherence of standard C.albicans strains, serotypes A and B, taking into consideration the cell line, the logarithmic phase of microorganism growth, the time of yeast contact, and the culture medium.

\section{MATERIALS AND METHODS}

C. albicans strains serotypes A (ICB 12) and B (ICB 156) were obtained from the Fungal Culture Collection of the

\footnotetext{
* Corresponding author. Mailing address: Instituto Adolfo Lutz, Seção de Microscopia Eletrônica, Av. Dr. Arnaldo, 355. 01246-902, São Paulo, SP. Tel: (+5511) 3068-2908 Fax: (+5511) 3088-3753. E-mail: patyfatima@hotmail.com
} 
Departmento de Microbiologia, Instituto de Ciências Biomédicas - Universidade de São Paulo. Growth curves were constructed for the standard strains using the viability test based on the fluorescence method of Corrêa et al. (5). Monolayers of HeLa and Vero cells were prepared and supplied by the Seção de Cultura Celular do Instituto Adolfo Lutz. A molar solution of sugars (glucose, sucrose, maltose, galactose and mannose) was sterilized by tindalization for a period of 3 days. An appropriate volume of stock solution was added aseptically to yeast nitrogen base (Difco) to obtain concentrations of $500 \mathrm{mM}$. Another glucose solution at concentration of $500 \mathrm{mM}$ was aseptically added to $3 \%$ peptone (Difco). The fungi were inoculated also onto Sabouraud glucose broth (Difco) as the standard medium. The material for scanning electron microscopy was prepared according to the protocol of the Seção de Estomatologia, Faculdade de Odontologia, Universidade de São Paulo. Examination by transmission electron microscopy was carried out using the technique of Kennedy and Sandin (19).

\section{Adherence assay (36)}

C. albicans strains were maintaned on Sabouraud-glucose agar (Difco) at room temperature and plated monthly. The yeast inoculum for adherence was prepared from the stock culture plated onto Sabouraud-glucose agar and incubated for $18 \mathrm{~h}$ at $37^{\circ} \mathrm{C}$. Four loopfuls of the culture were inoculated in yeast nitrogen base with the various sugars (glucose, maltose, sucrose, galactose and mannose), in Sabouraudglucose broth and in peptone water supplemented with 3\% glucose, and incubated at $37^{\circ} \mathrm{C}$ for 18 and $30 \mathrm{~h}$. The culture was centrifuged at $1500 \mathrm{rpm}$ for $10 \mathrm{~min}$ and the sediment washed once in PBS, pH 7.2. The concentration of cells in the final suspension was monitored by microscopy in a Newbauer chamber. A $2.5 \mathrm{ml}$ aliquot of the final suspension was aseptically added to each cell culture containing a monolayer of cells grown in Eagle medium, previously washed in PBS, $\mathrm{pH} 7.2$ and incubated at $37^{\circ} \mathrm{C}$ for $30 \mathrm{~min}$ and for $1 \mathrm{~h}$ with constant shaking (160 rpm). Coverslips were carefully removed and washed in PBS, pH 7.2, with light manual shaking. The coverslips with the adhered cells were fixed in $5 \%$ formalin for $30 \mathrm{~min}$ and air dried. The cells were stained by the Gram method and mounted on slides with synthetic resin (Araldite 502). Each experiment was carried out in triplicate. For adhered cell counts, yeasts with smaller buds than the mother cell were considered to be one cell, i.e., one hypha, one cell. Areas with discontinuous monolayers were not considered for counts. Five fields for 100 cells per slide were counted.

\section{Statistics}

Comparison between arithmetic means was made by Student's t test (1) when the populations were heterocedastic.

\section{RESULTS}

Experimental growth of serotypes A and B C. albicans started at $15 \mathrm{~h}$, with maximum growth being generally reached by about the third and fourth day, followed by a death phase. The stationary growth phase could not be well established in the strains studied. We performed an adherence assay an $18 \mathrm{~h}$ of culture considered with certainty to be the beginning of the $\log$ phase, with the middle log phase being reached after $30 \mathrm{~h}$, followed by a decline phase at about $72 \mathrm{~h}$.

The results concerning the formation of the cell wall and the number of layers in the yeast cells after culture on five different carbon sources in a chemically defined medium (YNB), Sabouraud-glucose and 3\% peptone water were as follows: for serotype A, the YNB containing sucrose was the most effective for the development of the cell wall of $C$. albicans, followed by the media containing glucose, maltose, galactose, mannose, the medium glucose plus 3\% peptone water, and Sabouraud-glucose. YNB with sucrose promoted the formation of 5 layers, followed by YNB with glucose (4 layers), maltose, galactose or mannose, the medium glucose plus 3\% peptone water and Sabouraud-glucose (2 layers). For serotype B, YNB-mannose promoted the growth of the thickest layer, followed by YNB-sucrose, UNB-maltose, Sabouraudglucose, glucose in 3\% peptone water, YNB-glucose, and YNBgalactose. YNB With glucose and mannose promoted the formation of 3 cell wall layers, whereas Sabouraud-glucose, YNB-maltose and YNB-galactose promoted the formation of 2 layers, and YNB-sucrose and glucose plus 3\% peptone water promoted the growth of 1 layer.

The fibrillar-floccular layer (adhesins) was observed for both yeast strains studied in all culture media tested. Tables 1 show the results (mean $\pm \mathrm{sd}$ ) obtained with the ICB-12 serotype A yeast cells, and Tables 2 show the results obtained with the ICB 156 serotype B strain. Comparison of the means by Student's $t$ test showed significant differences between the parameters studied. HeLa and Vero cells can be used interchangeably in the adherence assay of $C$. albicans serotypes $\mathrm{A}$ and $\mathrm{B}$ when cultured on the five different carbon sources and in chemically defined medium. This was not the case for $C$. albicans serotypes A and B when they were cultured in Sabouraud-glucose or in $3 \%$ peptone water, with adherence being significantly higher in HeLa than in Vero cells.

It should be pointed out that Vero cells are more sensitive, i.e., they are more easily destroyed in the presence of the yeast than HeLa cells. Among the chemically defined media, glucose as a carbon source proved to be efficient for both C. albicans serotypes, followed by mannose and sucrose for serotype A and mannose for serotype B. Maltose as a carbon source for serotypes A and B, galactose for serotype A and sucrose for serotype B were inefficient in the adherence assay under the conditions employed. Among chemically undefined media, 
Table 1. Number of adhered cells (C. albicans standard serotype A ICB-12) diferents medium and in HeLa and Vero cells during the two stages of the log phase, 18 and $30 \mathrm{~h}$, and at times of contact of $30 \mathrm{~min}$ and $60 \mathrm{~min}$

\begin{tabular}{|c|c|c|c|c|}
\hline \multirow{2}{*}{$\begin{array}{l}\text { Médium/ } \\
\text { Cells }\end{array}$} & \multicolumn{2}{|c|}{$18 \mathrm{~h}$} & \multicolumn{2}{|c|}{$30 \mathrm{~h}$} \\
\hline & $30 \mathrm{~min}$ & $60 \mathrm{~min}$ & $30 \mathrm{~min}$ & $60 \mathrm{~min}$ \\
\hline \multicolumn{5}{|c|}{ Glucose + YNB } \\
\hline $\mathrm{HeLa}$ & $31.46 \pm 25.12$ & $34.66 \pm 14.17$ & $92.70 \pm 43.18$ & $69.20 \pm 35.45$ \\
\hline \multicolumn{5}{|c|}{ Maltose + YNB } \\
\hline $\mathrm{HeLa}$ & $24.53 \pm 12.64$ & $10.46 \pm 3.75$ & \multirow{2}{*}{$\begin{array}{c}5.69 \pm 3.27 \\
\ldots\end{array}$} & $6.00 \pm 4.20$ \\
\hline Vero & $32.90 \pm 17.96$ & $25.66 \pm 17.13$ & & $20.50 \pm 14.92$ \\
\hline \multicolumn{5}{|c|}{ Sucrose + YNB } \\
\hline HeLa & $51.60 \pm 16.57$ & \multirow{2}{*}{$\begin{array}{c}33.60 \pm 10.55 \\
\ldots \text { —b }\end{array}$} & $26.80 \pm 8.95$ & $17.53 \pm 10.51$ \\
\hline Vero & $27.62 \pm 8.38$ & & $20.33 \pm 10.42$ & $17.00 \pm 7.80$ \\
\hline \multicolumn{5}{|c|}{ Galactose + YNB } \\
\hline HeLa & $28.46 \pm 9.26$ & $28.60 \pm 13.85$ & $23.20 \pm 8.26$ & $22.40 \pm 4.72$ \\
\hline \multicolumn{5}{|c|}{ Mannose + YNB } \\
\hline Hela & $41.40 \pm 38.56$ & $34.06 \pm 10.01$ & $32.53 \pm 10.57$ & $29.06 \pm 8.00$ \\
\hline $\begin{array}{l}\text { Vero } \\
\text { Sabourau }\end{array}$ & \multicolumn{3}{|c|}{ Sabouraud - dextrose } & $16.33 \pm 9.02$ \\
\hline Hela & $39.73 \pm 26.26$ & $44.26 \pm 28.16$ & $32.53 \pm 15.03$ & $32.53 \pm 25.31$ \\
\hline Vero & $10.46 \pm 6.94$ & $14.53 \pm 9.87$ & $21.80 \pm 9.86$ & $27.33 \pm 17.66$ \\
\hline \multicolumn{5}{|c|}{ Glucose $+3 \%$ peptone } \\
\hline HeLa & $44.86 \pm 16.34$ & $107.47 \pm 46.63$ & $53.70 \pm 34.28$ & $65.38 \pm 19.62$ \\
\hline Vero & $39.20 \pm 17.40$ & $114.13 \pm 42.90$ & $66.40 \pm 19.57$ & $64.60 \pm 22.88$ \\
\hline
\end{tabular}

Mean \pm standard deviation (SD); * Destroyed layer.

glucose plus 3\% peptone water promoted excellent adherence for serotype A and Sabouraud-glucose broth promoted good adherence for serotype B.

Comparison of the two stages of the log phase ( 18 and $30 \mathrm{~h})$ showed that adherence was higher at $18 \mathrm{~h}$ for both serotypes. Comparison of the times of contact showed that $30 \mathrm{~min}$ and 60 $\mathrm{min}$ are both satisfactory for the occurrence of adherence.

\section{DISCUSSION}

Experimental studies of Candida spp adherence have reported the use of a wide variety of cell types including cells of the mouth, vagina, uroepithelial cells, corneocytic epithelia, and gastrointestinal epithelia. In addition to cells from human volunteers or from animals, which may yield widely varying results, established cell lineages have been extensively employed in this adherence process. Among these cell lineages are HeLa cells, epithelial cells and intestinal cell lineages. Samaranayake and MacFarlane (34) have reported the adherence of $C$. albicans to a population of more uniform cells (HeLa cells) han desquamating epithelial cells.
The use of these established cell types has many advantaged over non-established cells, such as mouth cells which are invariably contaminated with the commensal flora and are difficult to dislodge even after repeated washes. It has also been reported that these cells are commonly "washed" by solutions present in saliva and electrolytes that may be contaminated with serum and food remains, in addition to being highly variable in terms of age and viability (42).

Eukaryotic cell lineages present more uniform characteristics and are more accessible to a wide gamut of experiments because of the absence of natural contamination of the monolayer (37). The Vero cell lineage, originating from monkey kidneys, roved to be more sensitive than the HeLa lineage, with areas of destructions probably due to the presence of a glycoprotein (Candida-toxin) previously observed in several strains of $C$. albicans (14).

Important parameters for adherence assays are the cell type used, factors linked to the microorganisms and to the cells themselves, and environmental factors (11). McMurrough and Rose (29) reported that glucan, mannan, protein and phosphorus levels are affected by different glucose concentrations. The 
Table 2. Number of adhered cells (C. albicans standard serotype B ICB-156) diferents in medium and in HeLa and Vero cells during the two stages of the $\log$ phase, 18 and $30 \mathrm{~h}$, and at times of contact of $30 \mathrm{~min}$ and $60 \mathrm{~min}$.

\begin{tabular}{|c|c|c|c|c|}
\hline \multirow{2}{*}{$\begin{array}{l}\text { Médium/ } \\
\text { Cells }\end{array}$} & \multicolumn{2}{|c|}{$18 \mathrm{~h}$} & \multicolumn{2}{|c|}{$30 \mathrm{~h}$} \\
\hline & $30 \mathrm{~min}$ & $60 \mathrm{~min}$ & $30 \mathrm{~min}$ & $60 \mathrm{~min}$ \\
\hline \multicolumn{5}{|c|}{ Glucose + YNB } \\
\hline $\mathrm{HeLa}$ & $53.26 \pm 21.48$ & $64.60 \pm 12.71$ & $66.93 \pm 16.95$ & $54.20 \pm 18.40$ \\
\hline Vero & $55.26 \pm 23.11$ & $60.40 \pm 8.36$ & $67.73 \pm 24.36$ & $45.40 \pm 11.79$ \\
\hline \multicolumn{5}{|c|}{ Maltose + YNB } \\
\hline HeLa & $35.86 \pm 10.75$ & $50.93 \pm 13.08$ & $38.33 \pm 12.60$ & $23.10 \pm 8.24$ \\
\hline Vero & $31.93 \pm 10.25$ & $30.26 \pm 4.59$ & $19.73 \pm 8.43$ & $32.00 \pm 13.65$ \\
\hline \multicolumn{5}{|c|}{ Sucrose + YNB } \\
\hline HeLa & $64.00 \pm 7.58$ & $9.50 \pm 18.75$ & — & $20.60 \pm 5.13$ \\
\hline Vero & $48.46 \pm 18.73$ & $35.28 \pm 18.79$ & $25.00 \pm 2.83$ & $34.33 \pm 18.54$ \\
\hline \multicolumn{5}{|c|}{ Galactose + YNB } \\
\hline HeLa & $44.70 \pm 14.38$ & $44.20 \pm 14.64$ & $39.50 \pm 6.6$ & $21.00 \pm 4.36$ \\
\hline Vero & $41.21 \pm 22.52$ & $55.40 \pm 15.51$ & ]$^{*}$ & $137.00 \pm 45.04$ \\
\hline \multicolumn{5}{|c|}{ Mannose + YNB } \\
\hline HeLa & $47.93 \pm 22.36$ & $49.40 \pm 7.26$ & $78.80 \pm 34.24$ & $52.60 \pm 12.20$ \\
\hline Vero & $83.93 \pm 34.22$ & $81.35 \pm 14.37$ & $142.90 \pm 23.91$ & $49.14 \pm 28.16$ \\
\hline \multicolumn{5}{|c|}{ Sabouraud - glucose } \\
\hline HeLa & $74.66 \pm 19.87$ & $140.73 \pm 20.25$ & $82.86 \pm 56.98$ & $53.13 \pm 14.76$ \\
\hline Vero & $69.60 \pm 27.03$ & $135.80 \pm 43.53$ & $47.80 \pm 19.62$ & $64.73 \pm 39.90$ \\
\hline \multicolumn{5}{|c|}{ Glucose $+3 \%$ peptone } \\
\hline HeLa & $49.06 \pm 14.83$ & $57.83 \pm 21.07$ & $51.50 \pm 16.27$ & $76.73 \pm 25.41$ \\
\hline Vero & — & $50.60 \pm 4.50$ & $103.93 \pm 27.92$ & $109.38 \pm 22.80$ \\
\hline
\end{tabular}

Mean \pm standard deviation $(\mathrm{SD}) ; *$ Destroyed layer.

limitation of phosphate alters the carbohydrate content of the cell wall due to the decrease in glucan and in total lipid content. Yeast cells growing in media supplemented with high concentrations of galactose, sucrose, glucose or maltose adhere better to surfaces than yeasts grown in media with low glucose concentrations (36). In a study of C. albicans strains isolated from patients, McCourtier and Douglas (28) observed good adherence when the yeast cells were grown in medium containing $50 \mathrm{mM}$ glucose, but adherence improved significantly when the cells were grown in media containing high galactose and sucrose concentrations $(500 \mathrm{mM})$. Several studies have demonstrated that culture media rich in carbohydrates such as glucose, sucrose, maltose, galactose and xylitol increase the adherence of Candida to epithelial cells and to dental acrylic surfaces (11). On the basis of the above studies, in the present experiment we used the five carbon sources most frequently cited in the literature (glucose, maltose, sucrose, galactose, and mannose) in a chemically defined medium and at the same concentration of $500 \mathrm{mM}$. The highest adherence was obtained in $500 \mathrm{mM}$ glucose both for C. albicans serotype A and serotype $\mathrm{B}$, followed by mannose and sucrose for serotype A and mannose for serotype B. These observations may be relevant if we consider that carbohydrate-rich diets may predispose individuals to oral infections with Candida (28).
The mechanisms by which carbohydrates can be to increase adherence may be related to the additional production of a fibrillar-floccular surface layer. The floccular layer is present as a "fuzz" around the cell wall measuring 100 to $400 \mu \mathrm{m}$ and seems to be of an anamorphous nature $(33,41)$. Occasionally this material may be distributed throughout the surface or may be localized $(15,27)$. In contrast, the fibrillar layer can be seen on the cell surface and appear as a series of small structures arranged perpendicularly around the cell, and may also be equally distributed throughout the cell $(2,25)$.

These structures have not yet been truly measured, but appear to be about 2-10 $\mathrm{nm}$ in diameter. Fibrils mediating the adherence of $C$. albicans to surfaces have also been observed $(27,31,41)$ and seem to be analogous to the fimbriae of bacteria $(8,36)$ which play an important role in the establishment of adherence (38). The precise chemical nature of these morphological structures is still unknown (11) but they represent distinct adhering entities with a high ability to adhere to epithelial cells. Kennedy and Sandin (16) obtained better yeast adherence in glucose + YNB medium than in medium with galactose + YNB. These investigators detected no significant differences in $C$. albicans adherence when the yeast was grown in YNB supplemented with $2.5 \%(\mathrm{w} / \mathrm{v})$ glucose or with minimal medium (MM, $1.0 \mathrm{~g} / 1$ ammonium sulfate and $1.0 \mathrm{~g} / 1$ monopotassium 
sulfate, $\mathrm{pH}$ 6.0) supplemented with glucose. In the present study, no significant differences were observed when standard serotype A and B strains were grown in glucose + YNB and glucose plus $3 \%$ peptone water.

Yeast cell adherence is also influenced by the growth phase of culture. Several reports indicate that contradictory results are obtained in terms of adherence during the different growth phases of the microorganism. King et al. (21) showed that the growth phase has a marked effect on the ability of yeast cells to bind to epithelial cells. These investigators reported that yeasts in the stationary phase, considered by them to be more than 15 $18 \mathrm{~h}$, showed higher adherence than during the exponential phase. In contrast, Segal et al. (38) observed high adherence of yeast cells during the exponential growth, while Ghannoum and Radwan (11) found no significant differences between the two growth phases. We should emphasize here the very short time (18 h) considered by King et al. (21) to be the stationary phase for the strains studied. When the growth curve was calculated to establish the exponential and stationary phase for these strains, the latter was not well established, as also observed by Corrêa et al. (5) in a study for the standardization of the method. Two stages of the $\log$ phase were defined, i.e., 18 and $30 \mathrm{~h}$, with the $18 \mathrm{~h}$ period providing higher adherence for both yeast serotypes.

Another interesting result was that in this phase the two standard strains presented the highest content of carbohydrates, proteins and lipids in their cell wall, as observed by Del Negro and Paula (personal communication). An extracellular metabolic product elaborated in the presence of sucrose may be responsible for the increased yeast adherence (36). This conclusion was based on the fact that the increase in adherence disappeared when the yeast cells were killed before incubation in medium containing sucrose. In the present study, sucrose promoted the formation of 5 layers on the cell walls of serotype A, but not of serotype B. McCourtier and Douglas (28) showed that $C$. albicans, when cultured in the presence of galactose, suffered a transformation in the composition of the cell wall and developed an abundant fibrillar-floccular layer that turned the yeast more resistant to the formation of spheroplasts and also more adherent. These observation are also based on studies by Tronchin et al. (41) who investigated the influence of the environment on the ultrastructure and cytochemistry of C. albicans.

Yeast concentrations (CFU) of $10^{2}$ to $10^{9}$ microorganisms $/ \mathrm{ml}$ have been tested in adherence assays (11). In general, microorganism adherence is related to the proportional increase in microbial density $(7,27)$. On the other hand, King et al. (21) observed that the saturation of blastospore receptor sites on epithelial surfaces was reached when the yeasts were present at concentrations of $5 \times 10^{5}$ and $5 \times 10^{8} \mathrm{CFU} / \mathrm{ml}$. However, the formation of yeast clusters or of co-adhesion and the presence of yeast cells already adhering to epithelial cells may be responsible for the increased adherence values observed when high microorganism concentrations were added to the assays.

Recently, Klotz and Penn (23) showed that the addition of a highly concentrated blastospore inoculum led to blastospore aggregation (self-adherence) and to a greater destruction of the intestinal cells used in the adherence study than to a normal random distribution of yeast cells. In the present study we used $1-2 \times 10^{5}$ yeast cells because this is an intermediate concentration range for adherence studies and because in previous assays we observed a lower percentage of the co-adherence phenomenon. Even so, we noted that strain ICB-12 (serotype A) still presented self-adherence more than did the ICB-156 strain (serotype B). In these experiments, counts of adhered yeast cells obviously did not include groups with co-adherence. It should be pointed out once again that comparison of the data obtained at various research laboratories is difficult because of the phenomenon of co-adherence between various strains of the yeasts studied, because of the different contact times used (10 min to $3 \mathrm{~h}$ ), the different growth phases studied, and the different culture media and incubation temperatures. We should also point out the intrinsic characteristics of each C. albicans strain determining the two serotypes.

The times of contact of $30 \mathrm{~min}$ to $1 \mathrm{~h}$ used in the present study for the standard strains, serotypes A and B, did not cause significant differences. A contact time of $1 \mathrm{~h}$ was also used by Kennedy (20) in study for the standardization of adherence, with good results. In a study of adherence, (Fig 1) concluded that multiple factors can rule the adherence of $C$. albicans $(43,44,45)$. Obviously, after the establishment of these first essential parameters, more in-depth studies should be conducted on a larger number of strains belonging to the various bioserotypes in order to better elucidate this complex host-parasite relationship.

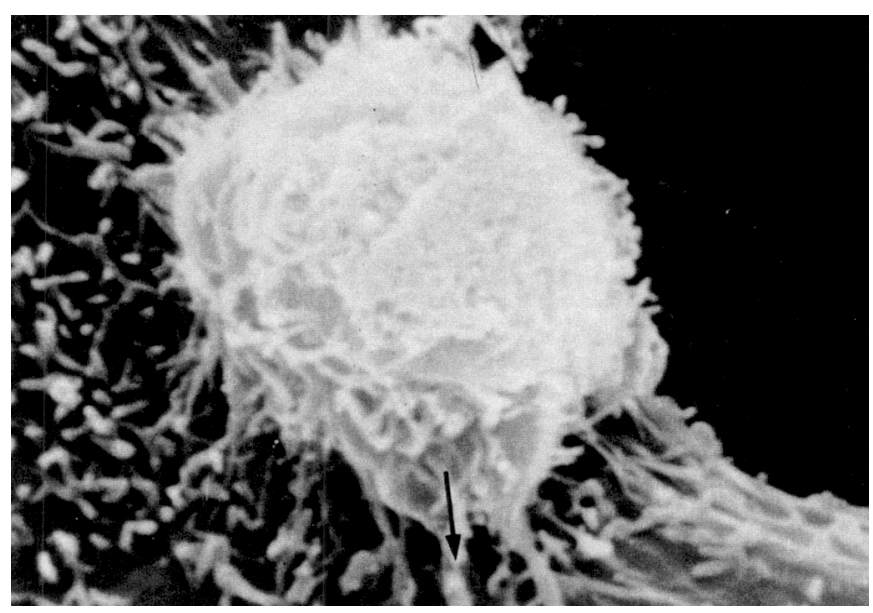

Figure 1. Scanning electron micrograph showing C. albicans (ICB-12) attached to HeLa cells. Contact is mediated by the fibrillar layer of the fungi. (X 6000). 


\section{ACKNOWLEDGMENTS}

We wish to thank Mr. Jonas José Kisielius for the transmission electron microscopy assays, Mrs. Ana Luiza K.N. Almeida for the scanning electron microscopy assays, Cristina Figueiredo for the cell culture and Maria Joana Eleotério, Sandra Fernanda Bilbao Orozco for excellent technical assistance.

\section{RESUMO}

\section{Modelo experimental de aderência de Candida albicans (sorotipos A e B) "in vitro"}

A aderência é considerada como um importante fator de virulência de Candida albicans por determinar a colonização dessas leveduras em diversas regiões do hospedeiro. É a causa inicial da infecção. Neste trabalho estudamos a aderência de $C$. albicans (sorotipos A e B) em culturas de células Hela e Vero, com leveduras cultivadas por 18 e 30 horas em meio YNB adicionado de fontes de carboidrato como glicose, sacarose, maltose, galactose e manose $(500 \mathrm{mM})$. Cada ensaio foi realizado em triplicata. Os melhores resultados foram obtidos no meio adicionado de glicose. A aderência foi maior em culturas de 18 horas, incubadas a $37^{\circ} \mathrm{C}$ no tempo de contato com as células de 1 hora. O estudo da interação entre as leveduras e a cultura de células foi realizado utilizando-se a microscopia eletrônica de varredura.

Palavras-chave: Candida albicans, aderência, sorotipos

\section{REFERENCES}

1. Arena, J.F.P. Estudo biométrico de recém-nascidos de uma brasileira. Rev. Paul. Med., 88:95-101, 1976.

2. Barnes, J.L.; Osgood, W.; Lee, J.C.; King, R.D.; Stein, J.H. Hostparasite interations with pathogenesis of experimental renal candidiasis. Lab. Invest., 49:460, 1983.

3. Beachey, E.H. Bacterial Adherence Receptors and Recognition. Chapman and Hal London, 1980.

4. Bennett, J.E.; Hay, R.J.; Peterson, P.K. New strategies in fungal disease., Glaxo Group London, 1992, 312p.

5. Corrêa, B.; Purchio, A.; Paula, C.R.; Gambale, W. Avaliação da eficiência do método de fluorescência no estudo da viabilidade de Candida albicans. Rev. Microbiol., 18:258-63, 1987.

6. Cox, F. Candida albicans adherence in newborn infants. J. Med. Vet. Mycol., 24:121, 1986

7. Cutler, J.; Brawner, D.L.; Hazen, K.C.; Jutila, M.A. Characteritics of Candida albicans adherence to mouse tissues. Infct. Immun., 58:1902, 1990.

8. Douglas, L.J.; Houston, J.G.; Mccourtie, J. Adherence of Candida albicans to human buccal epithelial cell after growth on different carbon sources. Fems. Microbiol. Lett., 12: 241,1981.

9. Douglas, L.J. Adhesion of pathogenic Candida species to host surfaces. Microbiol Sci., 2:243-247, 1985.

10. Douglas, L.J. Adhesion to surfaces. In: The Yeast. 2.ed., Academic Press, London, 1987.

11. Ghannoum, M.A.; Radwan, J.J. Candida adherence to epithelial cells. C.R. Press, Boca Raton, 1990, 270p.
12. Gibbons, R.J.; Van Houte, J. Selective bacterial adherence to oral epithelial surfaces and its role as na ecological determinant. Infect Immun., 3:567- 573, 1971.

13. Hazen, K.C.; Plotkin, B.J.; Klimas, D.M. Influence of growth conditions on cell surface hydrophobicity of Candia albicans and Candida glabrata. Infect. Immun., 54:269, 1986.

14. Iwata, K. Fungal toxins and their role in the etiopathology of fungalinfections. In: Recent advance in medical and veterinary micology. Ed. K. Iwata. Univ. Park Press, Tokio, 1975, 33p.

15. Howlett, J.A.; Squier, C.A . Candida albicans ultrastructure: Colonization and invasion of oral epithelium. Infect Immun., 29:252$260,1980$.

16. Kahama, M.; Segal, E.; Schewach Millet, M.; Gou, Y. "In vitro" adherence of Candida albicans to human corneocytes. Acta Dermatol. Venereol., 68:98-101, 1988.

17. Kalo, A.; Segal, E.; Sahar, E.; Dayan, D. Interation of Candida albicans with genital mucosal surfaces: envolvimet of fibronectin in adherence. J. Infect. Dis., 157: 1253-1256, 1988.

18. Kennedy, M.J.; Volz, P.A.; Edwards, C.A.; Yancey, R.J. Mechanisms of association of Candida albicans with intestinal mucosa. $J$ Med Microbiol., 1987.

19. Kennedy, M.J.; Sandin, R.L. Influence of growth conditions on Candida albicans adhesion, hydrophobicity and cell wall ultrastruture. J. Am. Mycol., 26:79, 1988.

20. Kennedy, M.J. Adhesion and association mechanisms of Candida albicans in current topics. In: M.C. Ginnis (ed) Medical Mycology. Academic Press, New York, 1988, 73p.

21. King, R.D.; Lee, J.C.; Morris, A. Adherence of Candida albicans and other Candida species to mucosal epithelial cells. Infect. Immun. 27:667, 1980 .

22. Klotz, S.A.; Drutz, D.J.; Zagic, J.E. Factors governing adherence of Candida species to plastic surfaces. Infect. Immun., 50: 97, 1985.

23. Klotz, S.A.; Penn, R.L. Multiple mechanisms may contribute to the adherence of Candida yeast to living cells. Curr. Microbiol., 16:119, 1987.

24. Klotz, J.; Smith, R.L. Gelatin fragments inhibit Candida albicans yeast adherence to ECM. Annual Meeting American Society of Microbiology, 1990, 100p.

25. Lee, J.C.; King, D.D. Characterization of Candida albicans adherence to human vaginal ephitelial cell "in vitro". Infect. Immun., 41:1024, 1983.

26. Macura, A.B. Hydrophobicity of Candida albicans related others adherence to mucosal epithelial cells. Zentralbl. Bakteriol. Mikrobiol. Hyg. 1. Abt. Org. A., 266:491, 1987.

27. Marrie, T.A.; Costerton, J.W. The ultrastruture of Candida albicans infections. Can. J. Microbiol., 27: 1156, 1981.

28. Mc Courtie, J.; Douglas, L.J. Relationship between cell surface composition, adherence and virulence of Candida albicans. Infect. Immun 45:6, 1984.

29. Mc Murrrough, I.; Rose, A.H. Effects of growth rate and substrate limitationonthe composition and atruture of the cell wallof Saccharomyces cerevisiae. Biochem. J., 105:189, 1967.

30. Pendrak, M.L.; Klotz, S.A. Adherence of Candida albicans to host cells. FEMS Microbiol. Lett., 129:103-114, 1995.

31. Rotrosen, D.J.E.; Ibson, T.R.; Moore, J.C.; Cohen, A.H.; Green, I. Adherence of Candida to cultured vascular endothelial cells: Mechanisms of attachment and endothelial cell penetration. J. Infect. Dis., 152:1264-74, 1985.

32. Rutter, P.R. Mechanisms of adhesion. In: MICROBIOL Adhesion and Aggregation. Ed. Springer-Verlag, 1984. p.5-19.

33. Sandin, R.L. The attachement to human buccal epithelial cells by Candida albicans an "in vitro" kinetic study using concanavalin A. Mycopathologia, 98:179, 1987.

34. Sandin, R.L.; Kennedy, M.J. Influence of growth parameters on Candida albicans adhesion, hydrophobicity, and cell wall ultrastruture. Infect. Immun., 1987.

35. Sandovsky- Losica, H.; Segal, E. Interation of Candida albicans with murine gastrointestinal mucosa: effect of irradiation on adherence "in vitro". J. Med. Vet. Mycol., 27:345-352, 1989. 
36. Saramanayake, L.P.; Mac Farlane, T.W. Na in vitro study of the adherence of Candida albicans to acrylic surface. Arch. Chal. Biol., $25: 603,1980$.

37. Saramanayake, L.P.; Mac Farlane, T.W. The adhesion of the yeast Candida albicans to epithelial cells of human origin in vitro. Arch. Oral Biol., 26:815, 1981.

38. Segal, E.; Lehrer, N.; Ofek, I. Adherence of Candida albicans to human vaginal epithelial cells: inhibition by amino sugars. Exp. Cell. Biol., 50:13, 1982.

39. Segal, E.; Sandovsky-Losica,H. Adhesion and interaction of Candida albicans with Mammalian tissues in vitro and in vivo. Methods Enzymol., 52:253-439, 1995.

40. Skerl, K.C.; Marshall, Berlin, K.G.; Calderone, R.A.; Segal, E.; Sreevalsan, T.; Scheld, W.M. in vitro binding of Candida albicans yeast cells to human fibronectin. Can. J. Microbiol., 30:221-7, 1984.
41. Tronchin, G.D.; Vernes, A. Cytochemical and ultrastructural studies of Candida albicans. III. Evidence for modification of the cell wall coat during adherence to human buccal ephitelial cells. Arch.Microbiol., 139:221-4, 1984.

42. Varian, S.A.; Cooke, E.M. Adhesive properties of Escherichia coli from urinary - tract infections. J. Med. Microbiol., 13:111, 1980.

43. Vespa, M.N.; Lopés-Ribot, J.L.; Chaffin, W.L. Adherence of germ tubes of Candida albicans to tissues from immunocompromised mice. FEMS Immun. Med. Microbil., 11: 57-64, 1995.

44. Watts, H.J.; Cheah, F.S.H.; Hube, B.; Sanglard, D.; Gow, N.A.R. Altered adherence in strains of Candida albicans harbouring null mutations in secreted aspartic proteinase genes. FEMS Microbiol Letters, 159:129-135, 1998.

45. Welmer, A.; Bernhardt H. Adherence on buccal epithelial cells and germ tube formation in the continuous flow culture of clinical Candida albicans isolates. Mycoses., 40:363-368, 1997. 